\title{
Chapter 15 \\ Between Community and Private \\ Ownership in Centrally Planned \\ Residential Space: Governing Parking \\ in Socialist Housing Estates
}

\section{Tauri Tuvikene}

\begin{abstract}
This chapter examines the problems of governing shared aspects of housing estates under the conditions of extensive privatisation in originally centrally planned and organised urban space. The management of car parking in housing estates illustrates the mismatch between initial planning ideas and contemporary governing of housing estates. Instead of the municipality replanning areas to deal with the 'parking problem', the municipality merely allocates parcels of its land for long-term lease to function as parking lots, with partial funds channelled for the formalisation of informal parking areas. On the one hand, the accommodation of individual cars in housing estates marks a departure from the neighbourhood unit principles that housing estates were meant to have. On the other hand, the responsibility of the city is also diminishing and that of lower level governing actors-flat-owners' associations (FOAs) - increasing. Nevertheless, due to their form, wherein streets, green spaces and buildings are interwoven, housing estates would require more central systems of governing than FOAs could provide, which is the reason 'governing through community' is on the rise. This paper discusses the questions through the case of Mustamäe in Tallinn, but many of the insights would be applicable for various other housing estates not just in Tallinn but also elsewhere in the formerly socialist world having a similar physical form and facing the challenge of accommodating parked cars.
\end{abstract}

Keywords Parking - Neoliberalism - Flat-owners associations - Housing estates • Tallinn

T. Tuvikene $(\bowtie)$

Centre for Landscape and Culture, School of Humanities, Tallinn University,

Tallinn, Estonia

e-mail: tauri.tuvikene@tlu.ee

(C) The Author(s) 2019

D. B. Hess and T. Tammaru (eds.), Housing Estates in the Baltic Countries,

The Urban Book Series, https://doi.org/10.1007/978-3-030-23392-1_15 


\subsection{Introduction}

The challenges of centrally planned housing estates in Europe extend beyond social problems. This is because housing estates are everyday living environments requiring typical maintenance including mowing grass, cleaning courtyards and sorting out mundane concerns, such as finding space to park cars. In societies where the principal form of urbanisation occurred through the construction of housing estates, such everyday worries become prominent. It is thus not surprising that the increasing challenge of accommodating automobile parking in housing estates, which has been exacerbated by rampant motorisation, has led to a condition described as the 'parking problem'. This condition is often felt as one of the most prominent concerns within housing estates, as illustrated in this chapter's case study of Mustamäe in Tallinn, Estonia (Heidmets and Liik 2012), and throughout the former Soviet Union (Vihavainen 2011).

In Estonia, as elsewhere in the former Soviet Union, private automobiles have turned from objects that are hard to acquire to a ubiquitous element within urban environments, with ownership trebling during the post-Soviet years from 161 cars per 1000 inhabitants in 1991 to 520 cars per 1000 inhabitants today (2017). Urban spaces have proved incapable of accommodating the increasing number of individual cars in existing parking spaces. In housing estates, this has meant the provision of additional parking spaces in unorganised ways, not overseen or managed by governmental authorities. Namely, residents have parked their cars on what used to be grass, thereby collectively transforming it into parking space (Fig. 15.1). Eventually, the city has supported such gradual and informal adaptation of land by legalising and formalising those parking spaces. Thus, the adaptation of the neighbourhood to cars and the city's support for it has generated a new vision of space in housing estates, whereby instead of the auto-mobility restrictions devised in the Soviet years, cars now hold a more prominent position.

The underlying design logic of housing estates was to restrict cars entering the courtyards by locating motor vehicle infrastructure, including parking lots, at the edges of super-blocks. Nowadays, it is common that cars are parked in rows alongside the front of the buildings or alongside the edges of green spaces. In this way, cars are driving frequently around at the inner courtyards. Yet some suggestions to move back to the Soviet ideas have also been proposed as ways to tackle the 'parking problem' in the Mustamäe General Plan (2006; see Fig. 15.2). Nevertheless, even though this plan was exhibited in the General Plan, it was never implemented in this spot and has not become a general guiding principle for the future practice of governing the area. Instead, 'parking problem' has remained to be solved by individual apartment buildings, and thus by small-scale solutions, which even so receive guidance and governing from city authorities.

Using the example of a 'parking problem' in housing estates, we see ways in which the centralised organisation of housing estates contradicts the conditions of privatisation. Since the privatisation of buildings and much of the land in housing estates, Estonia has not relied on large housing associations but opted for 


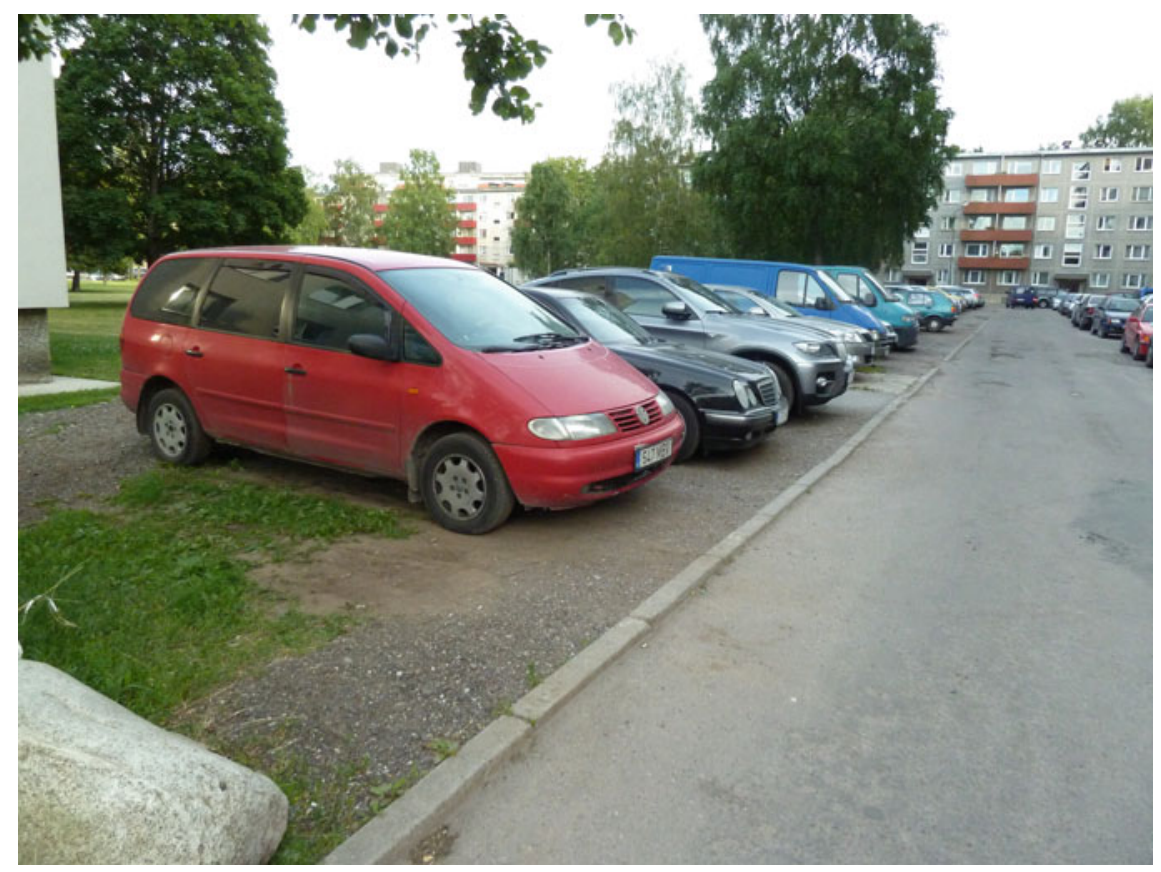

Fig. 15.1 Cars parked upon greenspace. Source T. Tuvikene (photo made in 2013)

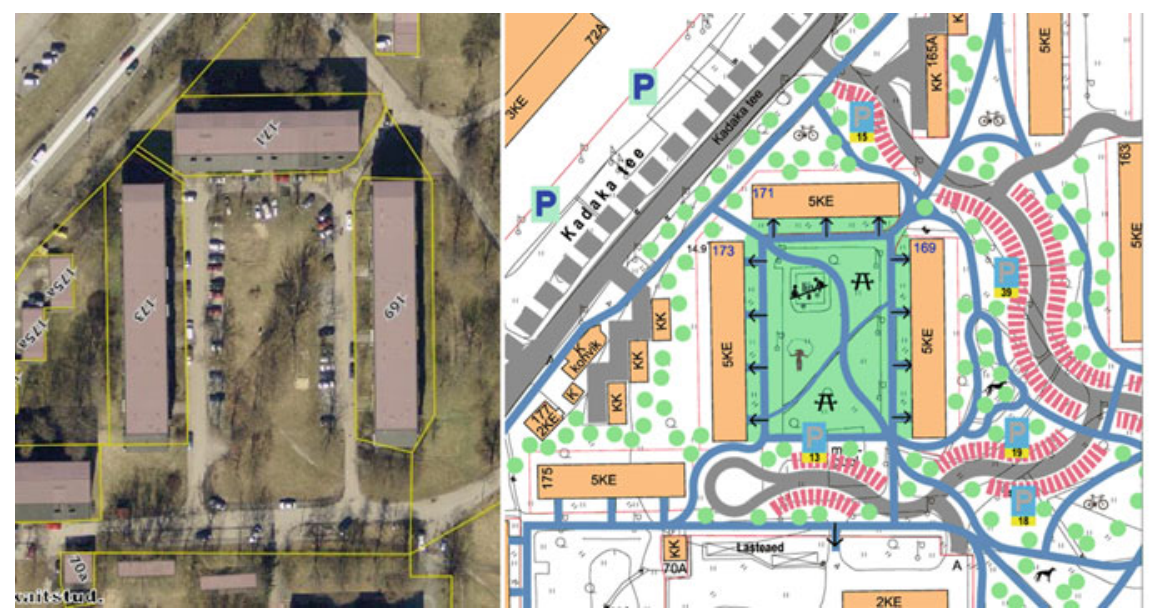

Fig. 15.2 Current configuration of parking space (left) and in the 2006 Mustamäe General Plan (right). The image on the left also highlights how cars are parked on shared spaces and not on the land owned by the FOAs. Sources Maa-amet, 2018 (https://xgis.maaamet.ee/maps/XGis, accessed 25 May 2018) (left; permission not required) and Mustamäe General Plan 2006 (right, permission not required) 
flat-owners' associations (FOAs) formed based on single apartment buildings as primary responsible actors not just dealing with their own building but also land beyond it. Provision and management of parking have become one of their duties. Nevertheless, the local state has remained active in direct solutions to the 'parking problem'. Yet the state acts only through the active involvement of citizens wherein communities form principal actors of governing (Cruikshank 1996; Mowbray 2011; Rose 1999; Tally 1999). The governing of housing estates takes place by 'governing through community' (Cheshire et al. 2009; Lanz 2013; Raco and Imrie 2000; Rose 1999). However, while usually claimed to be the result of shifting ideas on the modes of government reflecting historical emergence of neo-liberal sentiments, this paper also highlights that the way housing estates are planned has a role in the mode of governing that is utilised. Planning for parking has shifted from comprehensive mobility planning to a fragmented approach due to 'rolling path-dependencies,' (Bouzarovski et al. 2016) where early decisions to privatise form conditions for action in later stages. With this chapter, I show the ways in which housing estates necessitate centralised planning, where even in the condition of a fragmented approach the role of the active state has remained crucial, except now limited to act through apartment buildings.

This chapter focuses on Mustamäe, the oldest of the three major housing estates in Tallinn, constructed between 1964 and 1972, and today home to 68,000 residents in 11 micro-districts. My fieldwork in Mustamäe took place in 2012 as part of a wider research project on parking governance in Tallinn. I interviewed four city officials responsible for governing various aspects of parking, had conversations with a vice-mayor, and interviewed the Head of the Estonian Union of Cooperative Housing and six heads of flat-owners' associations. In 2014, I conducted a project on neighbourhood activism in Mustamäe, resulting in 16 interviews including 10 with heads of flat-owners' associations, which supported the claims in this paper. Living in Mustamäe in 2014 and 2015 contributed to the knowledge of the neighbourhood. For the historical part about Mustamäe, I have investigated original planning documents. Additionally, media reports and information on governmental tools in official documents provide a basis for analysis.

\subsection{Centrally Managed Housing Estates: Vehicular Mobility Restriction Plans}

If the aim was merely to provide as much housing as possible, buildings could have been aligned in rows in housing estates. Instead, building location and arrangement were carefully considered and the solution was 'micro-districts' which are the principal building blocks of housing estates. The principles of micro-districts are discussed comprehensively elsewhere in the book, but it is important to note here that they are not only inspired by Le Corbusier but parallel other neighbourhood utopias, such as the 'neighbourhood unit' proposed by Clarence Perry in the USA 
(see Ojari 2004). The planning ideas that housing estates draw from have a basis on three points: offering a significant amount of accessible greenery; spacing and arranging buildings such that dwellings receive ample sunlight, and planning traffic to improve safe pedestrian mobility. Such ideas were combined into the concept of the 'super-block' that proposed a significant expansion of the street block in order to maximize spaces for pedestrians and increase the green space that residents can access, especially without crossing a street (Panerai et al. 2004). Thus, micro-districts in housing estates are tackling important questions of providing healthy amounts of light for residents and offering easily accessible green spaces, but the design is considerably about traffic circulation, as well.

Housing estates considered transport in the way they were positioned within the urban spatial system, but also in the ways in which the inner courtyards were planned (Hess 2018). Following general transport planning principles of housing estates, the physical plan of Mustamäe set out to restrict the movement of cars inside residential quarters. On the one hand, the number of cars entering a block was limited by using the superblock/neighbourhood unit structure with wider streets at the outskirts and only small roads inside a block. On the other hand, blocking the possibility of driving through a superblock directly restricted vehicular mobility. To achieve this, some roads in the micro-districts were designed as cul-de-sacs (Southworth and Ben-Joseph 2004) that made it physically impossible to drive through. The first planning documents for Mustamäe from the early-1960s designated the cul-de-sacs (even though they were not called cul-de-sacs but rather 'dead-end streets'). While streets leading to the groups of apartment buildings were

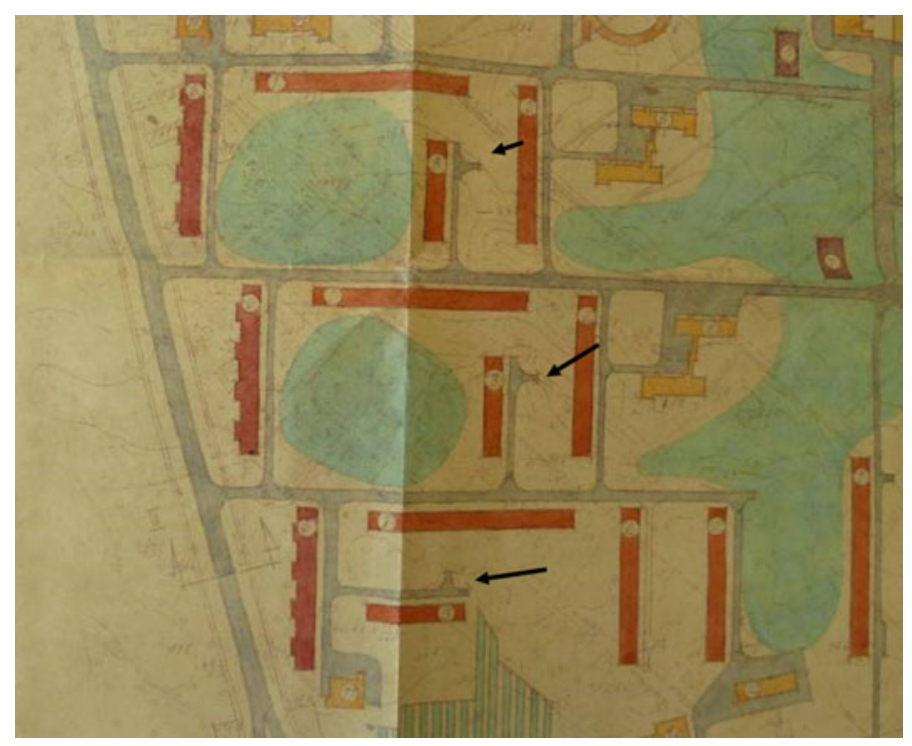

Fig. 15.3 Cul-de-sacs (shown with black arrows) are depicted in an earlier Mustamäe plan. Source National Archives of Estonia (Eesti Projekt 1964), permission not required 
designated to be $5.5 \mathrm{~m}$ wide, other streets leading to individual dwellings were merely 3.5 or $2.5 \mathrm{~m}$ wide. Streets that were $3.5 \mathrm{~m}$ wide were meant to have broader sections for overtaking and turnaround (Eesti Projekt 1964; see also Fig. 15.3).

In addition to the dead-end streets, the plan regulated automobile use by narrowing streets so that parking on them would not be possible (or would be possible only for a limited number of vehicles). Plans placed parking in garages at the outer parts of the micro-district. The wide streets surrounding superblocks, then, were intended to contain vehicular traffic, only entering close to the buildings infrequently to deliver something to an apartment or to take residents on board. A later plan for a refurbishment project in 1985 more thoroughly conceptualised the traffic management of cul-de-sacs.

\begin{abstract}
With the new traffic organisation, the aim has been to reduce driving through the micro-district. Vehicle traffic that would endanger pedestrians and children playing around buildings on streets in front of the apartment buildings is reduced... [W]ith the new traffic plan, dead-end streets are created in front of buildings. In order to curtail traffic, metal bollards are planned to be fitted into the road tarmac. (Kommunaalprojekt 1985, p. 5; author's translation)
\end{abstract}

In addition to cul-de-sacs, pedestrian circulation was not confined to the roads, but people could walk via direct routes through the courtyards and between buildings. This kind of pedestrian movement exhibits the thinking of Le Corbusier and Perry for whom the superblock form provided freedom for people on foot.

Thus, some of the ideas that housing estates embody in their material form of governing are more forward-looking than often discussed. Planning for pedestrians and restricting car mobility are important principles within the 'sustainable mobilities paradigm' (Banister 2008). I agree here with Dekker et al. (2005, p. 5) who propose that not only is it premature to claim that housing estates in Europe have reached the limits of their 'useful existence', but that 'large estates have an important part to play in promoting sustainable urban development more broadly, given their compact morphology, abundant open space, and their potential to benefit from public transport links and the development of green heating and energy systems'.

Housing estates expressed a comprehensive vision of mobility in accordance with Marxist-Leninist views of shared resources (Hess 2018). While Hess notes many inconsistencies with those principles already in the Soviet years, the shared vision was particularly altered with privatisation. The appearance and functioning of courtyards have remained a significant problem. The Development Plan for Housing notes:

The problem of multi-apartment residential areas is the upkeep of the areas between apartment buildings. While apartments are usually in private ownership and apartment buildings are managed by associations then courtyards between buildings are owned by local government or central state (or they are still on unreformed state land) and the associations do thus not have direct right, obligation or motivation to take care of those areas. Because of this, there is often a lack of landscaping, children playgrounds and resting places. (Majandus-ja Kommunikatsiooniministeerium 2008, p. 32; author's translation) 
The mismatch between the layout of housing estates and governing forms emerging with privatisation is a challenge that the city authorities seek to overcome through modes of governing through FOAs.

\subsection{Governing Housing Estates Through FOAs: The Challenges of Parking}

Housing estates on both sides of the Iron Curtain have been subject to privatisation and a general reduction of state control (e.g., Marcuse 1996; Murie et al. 2005). Such shifts, however, echo wider trends in societies. The diminishing state role has largely been captured by the notions of 'roll back' neoliberalism (Peck and Tickell 2002) wherein privatisation, deregulation and marketisation result in more freedom as well as responsibility leveraged on individuals. Yet, privatisations are also accompanied by the forms of 'roll-out' neoliberalism (Peck and Tickell 2002) meaning the extension of state capacities to spheres they were not an integral element of before. However, in modern societies governing is unable to direct the behaviour of individuals to the full extent but has to take into consideration their needs and wishes (see in particular Barry et al. 1996; Burchell et al. 1991; Dean 1996; Rose 1999; Rose and Miller 1992). A stream of research on governmentality has elaborated on governing techniques that rather than working against freedom, govern through freedom (Rose 1999). According to such interpretations of liberal governmentality, citizens are responsible for improving their own lives and bettering their conditions, while also improving society as a whole. Using these governing approaches, the state tries to accomplish its goals while investing less time and money in the welfare of individuals.

Estonia's strategy in terms of privatisation was a rapid transfer of assets from state ownership to that of individuals: in the case of housing estates, this was not done through restitution (see Feldman 1999) but vouchers given based on working years, through which former tenants of apartments could purchase their dwelling on very affordable terms (Kährik et al. 2004). Whereas $29 \%$ of dwellings were privately owned at the beginning of 1994, 5 years later in 1999, the percentage was already $93 \%$ (Statistikaamet n.d.). The shift was thus from the almost complete state ownership of housing at the end of the Soviet time (in 1991) to more than $97 \%$ of private ownership today (2014). Eventually, apartment buildings were transformed into condominiums with each tenant owning their apartment and a share of the land under the building and around it. Those two privatisations - dwelling and landhowever, were not coterminous, with the transfer of dwellings taking place sooner than the transfer of the surrounding territory. Nevertheless, with the two privatisations and diminishing tax bases of municipalities, the capacity for city authorities to initiate change and govern has been reduced.

With the central government decision to move towards private ownership and FOAs in the 1990s, individual apartment buildings have become the primary actors 
to take the responsibility of their living environment. It has been an understandable move from governmental authorities to attach other responsibilities to their agenda. The FOAs' field of responsibility has increased with the expectation that the organisation renovates the buildings and cares for parking lots, as well.

The neo-communitarian governing procedures, as they are conceptualised in political theory, follow 'roll-out neoliberalism' as outlined above and call for the third sector to act in improving economic development, social welfare and social cohesion (Fyfe 2005). These shifts in the UK and beyond, under frameworks of the Third Way or Big Society or other similar community-oriented state actions, call for the devolution of service functions to the 'third sector' by local state policies (Mowbray 2011). Rosol (2012), for instance, shows community volunteering in the case of community gardens as a neo-liberal strategy by local governors to provide green infrastructure, without needing to do the actual work, yet remaining in control of the situation. Similarly, FOAs in Estonia are formally third sector non-governmental organisations, a category that also includes citizen initiatives advancing political causes. Yet, in their function, FOAs fulfil a task that someone must do anyway (that is, maintain the building and take care of surrounding sites).

The conditions for the emergence of the 'neo-liberal' model of governing housing estates, with two components - active state and active individuals - present, are provided by the materiality of housing estates, as well as governmental pragmatism where almost all buildings (97\%), and large swathes of land are privatised: lacking finances and capacity to take lead in the management of public spaces in housing estates, the city government relies on time, money and organisational capacities of FOAs. While most of the buildings have privatised at least a certain portion of land, the privatisation of land has not led to a neat correspondence between spatial elements and their owners. That is, if the efforts by apartment buildings are not coordinated, problems will occur. First, the vast green space is not clearly belonging to one apartment building or another. The greenery is intermediary space in between apartment buildings belonging to everyone by the initial planning ideas. Formally, it mostly still does so today in Estonia as the greenery between buildings remains an unreformed property managed by district government or is fully municipalised. Thus, all the new borders drawn in the public space of housing estates appear as problematic in relation to the way it has functioned for decades. Second, designating a land plot around apartment buildings to belong to the FOA also means the inclusion of street sections providing access to other buildings (depicted in Fig. 15.4), which produces at least two problems: vehicular and pedestrian mobility to other buildings is compromised and responsibility for repair and maintenance of the road section is unclear. In the case of street privatisation, it then must be clearly designated who, under what conditions, can pass through the property to prevent ongoing conflicts between the residents of different buildings. If street sections for public use are privatised to FOAs, each FOA will have only a limited incentive to renovate and maintain the street, as many other buildings will benefit as well. An FOA would be funding services for other buildings from its own budget collected from the flat-owners. The research interviews with heads of FOAs indicated problems even with getting people within a 


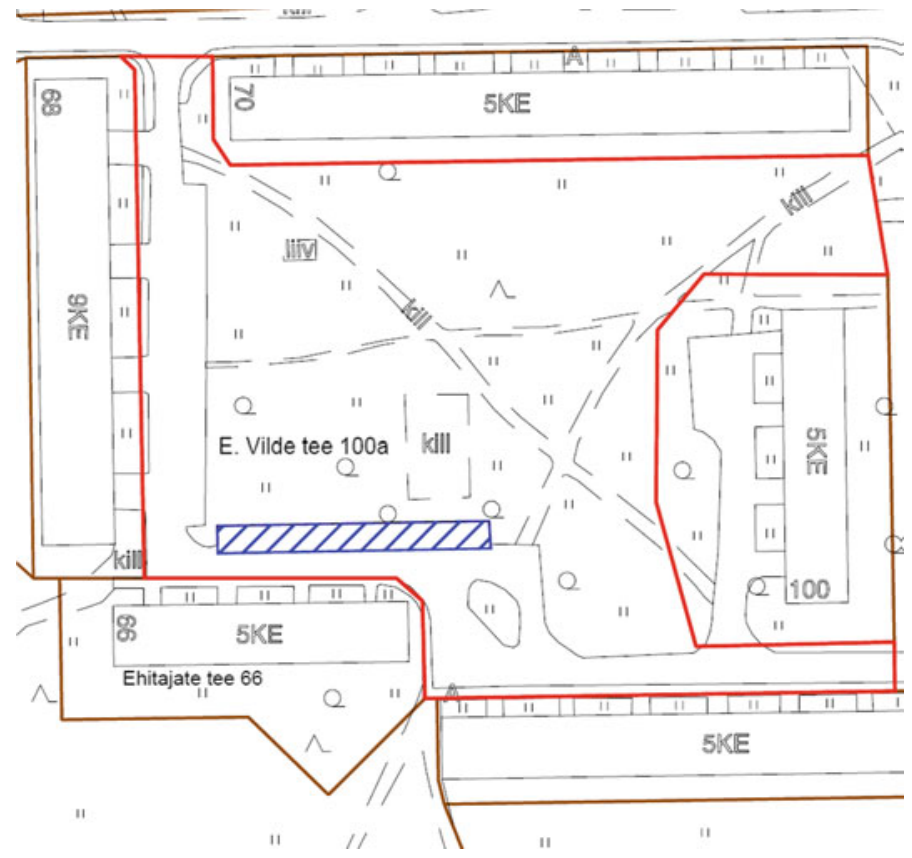

Fig. 15.4 An example of isiklik kasutusõigus [personal use right] for an apartment building, shown as striped areas. Note that street space is omitted. Source Tallinn City Government 2011b, permission not required

single FOA to accept costs of parking lots construction for own building use, making it even more problematic when the circle of users for those plots would be wider.

Streets inside blocks were not municipalised as 'transport land', as in other areas of the city, but were instead combined either with the building (rare option) or with the courtyard (more common). Land parcels are usually not gated as is usual in older city districts. The individualising use of various spatial elements thus extends beyond the mainly scant amount of land linked to one's apartment building (e.g. cutting branches of trees or maintaining flowers/bushes that are officially on the city land or parking informally on the green that legally belongs to the local government). Commenting on the privatisation process when the borders were being drawn, a councillor at the Mustamäe borough argued that in the superblock form of urban plan every piece of land belongs to everyone and it cannot be simply privatised (Hagelberg 1999). Thus, while the privatisation of housing and the Land Reform generated the context, whereby residents are organised into collectives based on apartment buildings with residents usually being the owners of their flats, much of the land in the neighbourhood has remained in collective use and in many cases in collective ownership (represented by the district government). Such physical space has required a wider level of intervention than current practice by the district government. 
The Development Plan for Housing (Majandus-ja Kommunikatsiooniministeerium 2008) cited above notes the mismatch between those who are and who city governors urge to be active in housing estates (that is FOAs) and the legal designation of land. Pragmatically, then, FOAs in housing estates are centres of deliberation, decision-making and activity inside these park-like structures, capable of showing interest and acting in the areas around them. With the number of flats usually around one hundred (if not more), such FOAs are quite powerful actors in governing and have emerged as pragmatic targets for taking over some of the responsibilities of governing housing estates. The state informs residents that addressing car parking - as well as many other issues in the housing estate - is their problem, but still intervenes in many ways to support their (pro-)activity. The city of Tallinn possesses a vision whereby FOAs lead the decision-making, not only in terms of their own buildings but also the surrounding land, whereas the vision includes that guidance is provided by the city authorities.

\subsection{Three Measures of Intervention in Parking in Housing Estates}

In recent years, the city of Tallinn has devised three measures that tackle the housing estate 'parking problem': (1) policy intervention; (2) funding support for parking provision; and (3) privatisation of the use of land. What is significant in all three measures is the way in which the city acts, doing so only through the proactive engagement of FOAs who are expected to be self-governing and responsible actors, following neo-communitarian and neo-liberalism principles.

The first of those measures - a particular policy scheme-was put together in 2012 by the city government to organise the provision of parking lots in residential areas. Even though it might look like a planning document that forms an agreement between different parties in terms of how and where the parking lots would be provided, it was merely an internal government document aimed to coordinate practices between departments to create parking lots. What is more significant, however, is the nature of the Scheme for Parking Provision (Tallinn City Government 2012). To my question as to whether the city prefers specific locations for the parking lots, officials at Mustamäe district government showed me a planning document ordered from a private company that mapped planned parking lots around apartment buildings (Interview 3). This document was prepared for less than one-third of the Mustamäe territory and it also did not show where parking lots should be built, but merely pointed out all the places where parking lots could potentially be constructed. As municipality officials stressed during an interview, parking spaces will be provided where FOAs requests them to be provided. Thus, even though the city had a specific policy for dealing with the parking problem (and no more recent policies have emerged as stated in follow-up phone interview, 
Interview 6), the policy was not the blueprint for action, but instead merely an idea that could be transformed into practice when FOAs show initiative.

The second measure applied by the city is funding provided for parking lot construction. The most important of those financing measures is a programme Hoovid Korda (direct translation is 'courtyards into order'). Since 2006, the programme annually supports approximately 70 applicants to carry out a diverse range of projects in courtyards. Projects range from locked sheds for garbage collection to providing children's playgrounds, and more recently including locked storage spaces for bicycles and murals on walls. The range of funded courtyard improvements has thus gradually expanded. The programme has also been important for funding the refurbishment of parking spaces, which is reportedly one of the key developments to be supported through this measure (Interview 6). Despite the funding by the city, however, a significant portion still needs to be provided by city residents. The programme covers no more than $70 \%$ of applicants' construction costs, with the funding percentage often much lower, even as low as $18 \%$ (Interview 6). Moreover, there is a cap on the funding amount of 15,980 EUR per year per applicant and no more than 39,950 EUR in three consecutive years. The average funding received by FOAs remains about three times lower than the maximum amount of annual funding (5,643 EUR in 2016). Parallel to the funding programmes for energy efficiency renovations for apartment buildings, this funding programme assumes that each FOA is capable of securing finances among the apartment owners of the building. The programme, moreover, is competitive. While in 2010, the number of successful applications for the whole city was $68 \%$ (with 22 projects from 30 that applied in Mustamäe got funding), a year later the share for the whole city had dropped to $43 \%$ (with only 7 projects from 31 funded in Mustamäe) (Tallinn City Government 2011a). In 2016, there were 128 applications and 90 projects that received funding, equivalent to a $70 \%$ success rate for applications. The total budget for projects has gradually increased and is now more than a half million EUR. In response to my question as to how the selection of applicants is done and whether there is an underlying principle about where parking lots should be provided in the housing estate, the officials claimed the decisions were based on the merits of the application rather than the logics of urban planning (Interview 5). In advancing their parking options, hence, apartment buildings can compete for the city funding which requires at least one-third of self-funding.

The third measure for the municipality to be involved in 'easing the parking problem' of FOAs, as the vice-mayor claims in the local borough newspaper (Vorrk 2012), is by offering the use of municipal land to individual FOAs. Namely, the city has opened the opportunity to enclose a portion of land for the exclusive use of a single building (Rattus 2012). While some apartment buildings decided and managed to privatise a larger land plot around their buildings, including parking lots and would thus not need land from the city, other FOAs have now acquired the 'personal right to use' on the city land. 'Personal right to use' is a freely-given 15-year rental agreement with the city for the utilisation, including maintenance and renovation of parking space (only, and not including street; see Fig. 15.4). The existence of such a governmental tool, as city authorities (Interview 3) have claimed, is 
a result of the demands of FOAs. Either those FOAs that had formalised their parking lots and financed it fully or half from their own budgets, felt it unjustified that cars from other buildings could also use the land (Interview 3). FOAs, having received the right from the city to use a land plot exclusively for a particular apartment building, then hired private companies to enforce parking. In this way, following Vihavainen's (2011) claims, FOAs have created a 'club good' out of 'common good'. By the end of 2017, Tallinn personal right to use has been set for 71 parking lots for 1,800 parking spaces in total (Kesknädal 2017).

While the city constructs some parking spaces in the course of road renovations, the main form for parking provision in housing estates remains through FOAs with plans, advice, partial funding and right to use city owned land offered. In practice, then, parking spaces that cars have already taken over are formalised with various helping measures from city authorities. As cars are considered unavoidable inside the blocks by city authorities the organisation and understanding of the physical space moves further away from the underlying planning ideas of Mustamäe and those of the 'neighbourhood unit'. The Scheme for Parking Provision (Tallinn City Government 2012; author's translation; no page number) states that the construction of '[a]dditional parking spaces adjacent to dwellings takes place by reducing greenery and increasing somewhat the traffic in the residential quarter.' Moreover, new projects for parking lot renovation often contain pavements for pedestrians, suggesting an increase of elements that, according to the superblock planning ideas, are not even necessary: traffic should be scarce enough that pedestrians and cars can share the interior street space. Thus, the state involvement has not so much meant a comprehensive re-drawing of informally generated mobility practices but rather accommodated them. Nevertheless, as was argued here, despite the individualised and fragmented measures, the state still administers developments by not allowing extensive private encroachments (gates and fences are forbidden, for instance) and by slightly nudging the process of improvements.

\subsection{Conclusion}

This chapter showed that while there are policies and measures by the city to deal with the parking problem, these governing tools expect FOAs to be in many ways 'entrepreneurial, self-responsible' actors (Larner 2003, p. 511) who manage their own matters themselves. The city thus has policies that resemble neo-liberal tools of governing. The arts of governing car parking in Mustamäe involve techniques such as governing at the distance and through the freedom of individual actors. Nevertheless, it is in many ways a pragmatic response to the physical conditions of housing estates in a situation, wherein most of the buildings and land under buildings are privatised and governments are cut short of financial means. Housing estates were initially state projects organised around centralised governing modes in either welfare states or communist governments. The space in micro-districts is difficult to parcel due to the way in which public and private spaces are intertwined, 
even if the intention is to move towards increasing individual governing. The large swathes of land between buildings fall under city ownership in Mustamäe and requiring actions by some actors on more general scale than individual buildings. The city must act somehow, but pragmatically, action is only possible through FOAs.

Through privatisation of residential blocks, FOA decision-making becomes a pragmatic governing solution. The city is not providing parking lots in a top-down way because it does not have to (FOAs have been created and are capable in taking over the tasks) and because it cannot do so (as there are no finances that would match the tasks). Hence, the introduction of the schemes for parking regulations devised by the city authorities and enacted through the actions of FOAs.

The materiality of the physical space mattered in this chapter in at least three ways. First, the materiality led to a problem - the 'parking problem' - as the physical plan could not accommodate increasing car ownership levels. Soviet housing estates-and Mustamäe as the oldest housing estate in Tallinn in particular - were planned for low car-use and utilised a model whereby large numbers of cars were not planned to operate inside superblocks. An increase in car use in Tallinn that creates a new, car-oriented reality in housing estates, radically transforms the original concept of the superblock. Such a model, generated by the recurring activities of cars, has also received backing from the local government who devise policy and offer funding and land for parking lots. Secondly, the physical reality of housing estates necessitates at least some forms of centralised governing. Site layouts make laissez-faire approaches impossible and require responsible actors on a more encompassing scale than a single building. Buildings, streets and courtyards are all enmeshed so that privatising a building with the land beneath it can be done, but privatising more than that leads to immediate conflicts with other buildings because streets and courtyards are for collective use. This actor, on a more encompassing level in Tallinn, has been local authority and mainly its district branch. Thirdly, the way buildings are positioned - as centres in vast green areasalso makes them possible centres for decision-making and action. The members of FOAs routinely show interest in their surroundings even if it is not the land they own: trees, bushes, green plots and parking spaces around a particular apartment building all fall within the area that residents from that FOA actively use.

This chapter draws attention to the necessity of governing modes that are on a more encompassing level than individual apartment buildings for managing housing estates. Currently in Tallinn, this governing mode is relying on certain centralised policies with funding and assistance, but with the main activities carried out by FOAs. Yet, there could be alternative means of achieving the same ends. For instance, new non-governmental organisations responsible for one micro-district could be formed as a true manifestation of neighbourhood-based governing (Somerville et al. 2009). Indeed, Perry (2001 [1929]) envisioned his neighbourhood units of 1920s as platforms for fostering citizenship. Some change in moving towards new means of more collective forms of governing is manifested by citizen initiatives, including non-governmental organisations such as Lasnaidee, in the newest socialist housing estate in Tallinn. Similarly, roundtables for FOAs in 
various housing estates have emerged enabling heads of FOAs to share experiences and enhance mutual learning. Studies I carried out about neighbourhood activism in Mustamäe in 2014 also revealed some small initiatives of cross-FOAs cooperation, such as building a children's playground and finding ways to collectively manage the task of mowing grass in a shared courtyard. Nevertheless, there is much to be done to achieve a better balance between the physical form and the institutional forms of housing estates governance.

\subsection{List of Interviews}

Interview 1 (14 March 2012) — a former municipality official in environmental matters and architect (one of the Mustamäe General Plan authors)

Interview 2 (7 May 2012) — an official in the urban planning department (an expert in general planning)

Interview 3 (9 July 2012) - a city official in Mustamäe city district government Interview 4 (17 July 2012)-Head of Estonian Union of Cooperative Housing Interview 5 (23 August 2013) - Two city officials dealing with the programme Hoovid Korda ('Courtyards into order')

Interview 6 (16 March 2018) - Phone interview with city official dealing with the programme Hoovid Korda ('Courtyards into order').

Acknowledgements The research was supported by the Archimedes Foundation, CEELBAS and Estonian Research Council grant PRG398.

\section{References}

Banister D (2008) The sustainable mobility paradigm. Transp Policy 15(2):73-80. https://doi.org/ 10.1016/j.tranpol.2007.10.005

Barry A, Osborne T, Rose N (1996) Foucault and political reason. The University of Chicago Press, Chicago

Bouzarovski S, Sýkora L, Matoušek R (2016) Locked-in post-socialism: rolling path dependencies in Liberec's district heating system. Eurasian Geogr Econ 57:624-642. https://doi.org/10.1080/ 15387216.2016.1250224

Burchell G, Gordon C, Miller P (1991) The foucault effect: studies in governmentality. The University of Chicago Press, Chicago

Cheshire L, Rosenblatt T, Lawrence G, Walters P (2009) The governmentality of master planning: housing consumption, aesthetics and community on a new estate. Hous Stud 24(5):653-667

Cruikshank B (1996) Revolutions within: self-government and self-esteem. In: Barry A, Osborne T, Rose $\mathrm{N}$ (eds) Foucault and political reason: liberalism, neo-liberalism and rationalities of government. The University of Chicago Press, Chicago, pp 231-252

Dean M (1996) Foucault, government and the enfolding of authority. In: Barry A, Osborne T, Rose N (eds) Foucault and political reason: liberalism, neo-liberalism and rationalities of government. The University of Chicago Press, Chicago, pp 209-230 
Dekker K, Hall S, Van Kempen R, Tosics I (2005) Restructuring large housing estates in European cities: an introduction. In: Van Kempen R, Dekker K, Hall S, Tosics I (eds) Restructuring large housing estates in Europe. The Policy Press, Bristol

Eesti Projekt (1964) Mustamäe IV mikrorajooni hoonestamise eskiisprojekt (Available in the archive: The National Archives of Estonia, ERA.T-14.4-6.8748)

Fyfe NR (2005) Making space for "neo-communitarianism"? the third sector, state and civil society in the UK. Antipode 37:536-557. https://doi.org/10.1111/j.0066-4812.2005.00510.x

Hagelberg T (1999) Korter tuleb hauda kaasa võtta [The apartment must be taken to the grave with you]. Luup, 6(89)

Heidmets M, Liik K (2012) Mustamäe arenduspiirkonna (I, II ja III mikrorajoon) elanike hoiakud ja valmisolek osalemiseks piirkonna ümberhoonestamisel. Tallinn University

Hess DB (2018) Transport in mikrorayons: accessibility and proximity to centrally planned residential districts during the socialist era, 1957-1989. J Plan Hist 17(3):184-204. https://doi. org/10.1177/1538513217707082

Kährik A, Lux M, Kõre J, Hendrikson M, Allsaar I (2004) Eluasemepoliitika üleminekuriikides [Housing policy in transitional countries]. Praxis, Tallinn

Kesknädal (2017) Eha Võrk: Pealinn teeb korteriühistutega tõhusat koostööd. http://www. kesknadal.ee/est/uudised?id=29491, 15 March 2018

Kommunaalprojekt (1985) Mustamäe II mikrorajooni kapitaalremondi tööprojekt (Available in the archive: Riigiarhiiv, ERA.T-2.4.1.10904)

Lanz S (2013) Be Berlin! governing the city through freedom. Int J Urban Reg Res 37:1305-1324. https://doi.org/10.1111/j.1468-2427.2012.01195.x

Larner W (2003) Neoliberalism? Environ Plan D: Soc Space 21(5):509-512

Majandus-ja Kommunikatsiooniministeerium (2008) Eesti eluasemevaldkonna arengukava 20082013. https://www.mkm.ee/et/eesmargid-tegevused/ehitus-ja-elamumajandus/elamumajandus, 8 Oct 2017

Marcuse P (1996) Privatization and its discontents: property rights in land and housing in the transition in Eastern Europe. In: Andrusz G, Harloe M, Szelenyi I (eds) Cities after socialism. urban and regional change and conflict in post-socialist societies. Oxford, Blackwell, pp 119191

Mowbray M (2011) What became of the local state? neo-liberalism, community development and local government. Commun Dev J 46:1132-i153. https://doi.org/10.1093/cdj/bsq051

Murie A, Tosics I, Aalbers M, Sendi R, Černič Mali B (2005) Privatisation and after. In: Van Kempen R, Dekker K, Hall S, Tosics I (eds) Restructuring large housing estates in Europe. The Policy Press, Bristol, pp 85-103

Mustamäe General Plan (2006) Mustamäe linnaosa üldplaneering. Tallinn: Tallinna Linnaplaneerimise Amet (prepared by E-Konsult and AB Koot and Koot). https://www. tallinn.ee/est/ehitus/Mustamae-linnaosa-uldplaneering-Kehtestatud, 25 May 2018

Ojari T (2004) Elamispind. Modernistlik elamuehitusideoloogia ja Mustamäe [Floor space: the modernist residential housing ideology and Mustamäe]. Kunstiteaduslikke Uurimusi (Studies on Art and Architecture) 13(2):42-70

Panerai P, Castex J, Depaule J-C (2004) Urban forms: the death and life of the urban block. Architectural Press, Oxford, Auckland, Boston, Johannesburg, Melbourne, New Delhi

Peck J, Tickell A (2002) Neoliberalizing space. Antipode 34(3):380-404

Perry C (2001) The neighbourhood unit. Routledge/Thoemmes Press, London

Raco M, Imrie R (2000) Governmentality and rights and responsibilities in urban policy. Environ. Plan. A 32:2187-2204. https://doi.org/10.1068/a3365

Rattus S (2012). Ühistud saavad parkla ehitamiseks tasuta maad. Pealinn, p 8

Rose N (1999) Powers of freedom: reframing political thought. Cambridge University Press, Cambridge, UK

Rose N, Miller P (1992) Political power beyond the state: problematics of government. Br J Sociol 43(2):173-205

Rosol M (2012) Community volunteering as neoliberal strategy? green space production in Berlin. Antipode 44:239-257. https://doi.org/10.1111/j.1467-8330.2011.00861.x 
Somerville P, Beckhoven EV, Kempen RV (2009) The decline and rise of neighbourhoods: the importance of neighbourhood governance. Int J Hous Policy 9(1):25-44. https://doi.org/10. 1080/14616710802693557

Southworth M, Ben-Joseph E (2004) Reconsidering the cul-de-sac. Access: Transp Res Univ Calif 1(24):28-33

Tallinn City Government (2011a) An answer to the request of information regarding Hoovid Korda programme by Urmas Mardi (LV-1/8195; 20 Nov 2011). https://aktal.tallinnlv.ee/static/ Aruparimised/Dokumendid/apvdok1016.pdf, 21 July 2014

Tallinn City Government (2011b) The city ordinance no. 367-k. Tallinna linna omandis olevale Eduard Vilde tee 100a kinnisasjale isikliku kasutusõiguse seadmine korteriühistu Kosmos kasuks [Setting private use right for FOA Kosmos on a city of Tallinn property with an address Eduard Vilde tee 100a] (14 Mar 2011)

Tallinn City Government (2012) Elamukvartalitesse lisaparkimiskohtade rajamise kava, Order no. 467

Tally J (1999) The agonic freedom of citizens. Econ Soc 28(2):161-182

Vihavainen R (2011) Common and dividing things in homeowners' associations. In: Kharkhordin O, Alapuro R (eds) Political theory and community building in post-soviet Russia. Routledge, London, pp 139-163

Võrk E (2012) Üheksakümmend uut parkimisala korrusmajadele [90 new parking areas for apartment buildings]. Mustamäe Leht, p 4

Open Access This chapter is licensed under the terms of the Creative Commons Attribution 4.0 International License (http://creativecommons.org/licenses/by/4.0/), which permits use, sharing, adaptation, distribution and reproduction in any medium or format, as long as you give appropriate credit to the original author(s) and the source, provide a link to the Creative Commons license and indicate if changes were made.

The images or other third party material in this chapter are included in the chapter's Creative Commons license, unless indicated otherwise in a credit line to the material. If material is not included in the chapter's Creative Commons license and your intended use is not permitted by statutory regulation or exceeds the permitted use, you will need to obtain permission directly from the copyright holder. 